\title{
MODEL PEMBERDAYAAN MASYARAKAT EKOLOGIS KULTURAL UNTUK PENYELAMATAN MATA AIR DI KOTA BATU
}

\author{
Rachmad K Dwi Susilo \\ Jurusan Sosiologi FISIP \\ Universitas Muhammadiyah Malang
}

\begin{abstract}
The construction of the hotel that was opposed by the users of water resource triggered the emergence of social movement. While inititating movement, they initiated the programs of community empowerment as well. It means that the community empowerment is one of strategies of movement. Then, besides focusing on cultural activities, the other activities are the optimization of youth potentials and the care about community activities. In this context, the ecological cultural is joined by the other community interests. This strategy is effective because the empowerment stimulated the development of social network and local culture. The critic of this empowerment is culture is not a central of activities. The culture is still used as instrument for the conservation of environment. This stance is always questioned and criticized by the environmental and cultural activists in Malang Town. This article will describe the model of cultural ecological empowerment in Batu City that is described from the emergence of community empowerment, the forms of the community empowerment, the form of social changes after interventions, and the strengths and weaknesses of this empowerment. This article utilized the descriptive research method with ethnographical approach. Meanwhile, the used sampling is purposive sampling with eight subjects of research are activists of Nawakalam Gemulo, community based organization in Cangar Hamlet, Bulukerto Village, Batu City.
\end{abstract}

Keywords: empowerment, ecology, culture

\section{PENDAHULUAN}

Persoalan lingkungan sudah masuk ke ranah sosial dan politik akhir-akhir ini. Salah satunya yaitu hak-hak warga atas lingkungan yang baik dan sehat telah menjadi isu-isu publik kelompok-kelompok peduli lingkungan. Selain menuntut hak-hak lingkungan, wacana ekologis ini bertujuan membuka kesadaran tentang parahnya kondisi lingkungan akhir-akhir ini.

Terlebih di era otonomi daerah, di mana pemerintah daerah memiliki kewenangan besar untuk mengeruk Sumber Daya Alam (SDA) di wilayah mereka. Hal ini dikarenakan Sumber Daya Alam (SDA) diandalkan sebagai sumber suatu kota/kabupaten. Pada konteks seperti ini, keberlanjutan ekologis, budaya, dan keselarasan sosial sering dikesampingkan, akibatnya rentan terjadinya konflik-konflik sosial. Oleh karena itu, peran masyarakat sipil diharapkan mampu mengontrol perilaku negara dan mempelopori langkah-langkah konservasi lingkungan yang berbasis kemandirian. Salim menyatakan bahwa masyarakat sipil berperan penting untuk menciptakan pembangunan berkelanjutan, di mana keberlanjutan lingkungan dan keselarasan sosial dapat diwujudkan (Atkinson \& Hammersley, 2007:28).

Untuk memperkuat peran masyarakat sipil tersebut perlu dilakukan pemberdayaan 
masyarakat, karena pemberdayaan dapat memampukan masyarakat untuk berperan pada konservasi lingkungan. Terkait dengan ini, penting meneliti kemunculan dan perkembangan organisasi Nawakalam Gemulo di Dusun Cangar, Desa Bulukerto, Kota Batu. Nawakalam Gemulo menujukkan kiprah anak-anak muda Dusun Cangar, Desa Bulukerto yang mengembangkan kreativitas, kemandirian komunitas, dan kepedulian kepada sumber air. Organisasi ini berhasil menginisiasi kegiatan-kegiatan pemberdayaan masyarakat, seperti kampanye kepedulian sumber mata air, menggali potensipotensi anak muda dan menyelenggarakan kegiatan-kegiatan ekologis kultural.

Penelitian ini memfokuskan kepada model pemberdayaan masyarakat berbasis lingkungan dan budaya lokal untuk penyelamatan sumber mata air. Model ini bisa menjadi alternatif atas praktik program konservasi lingkungan yang bersifat frontal atau berhadap-hadapan langsung dengan negara. Pemberdayaan ekologis kultural tidak menghadap-hadapan antara masyarakat deegan negara, perlawanan dilakukan dengan sindiran-sindiraan atau perlawanan tidak langsung.

Berangkat dari latar belakang di atas, artikel ini akan menjawab pertanyaan penelitian yaitu bagaimana model pemberdayaan masyarakat ekologis kultural di Kota Batu? Kemudian pertanyaan tersebut dirinci dalam pertanyaanpertanyaan antara lain (a) bagaimanakah kemunculan pemberdayaan masyarakat berbasis lingkungan dan budaya lokal di Dusun Cangar, Desa Bulukerto?, (b) bagaimanakah bentukbentuk pemberdayaan masyarakat tersebut?, (c) bentuk-bentuk perubahan sosial yang terjadi pasca pemberdayaan?, dan (d) apakah kelebihan dan kekurangan dari pemberdayaan masyarakat ini?

Susilo (2008) menyatakan bahwa pemberdayaan berasal dari kata "daya" yang berarti kemampuan atau kekuatan. Sementara itu, esensi pemberdayaan seperti dinyatakan oleh Stuart Ress yaitu proses perolehan kekuasaan (achieving power), termasuk di dalamnya perubahan sikap, perilaku, dan tindakan politik untuk memperoleh kekuasaan tersebut. Pada konteks komunitas, (Dharmawan, 2002) menyatakan bahwa pemberdayaan yaitu sebuah upaya perubahan (kemajuan) yang sengaja (purposive) dilakukan atau dikembangkan oleh para anggota komunitas itu sendiri. Di mana mereka mencemaskan masalah, menyusun sebuah rencana, menentukan arah perubahan menurut keyakinan dan persepsi mereka sendiri, dan perubahan itu diyakini sebagai perbaikan. Upaya perbaikan tersebut diarahkan kepada perbaikan dan pengokohan struktur-struktur penopang komunitas tersebut.

Sementara itu, Subejo dan Supriyanto (dalam Mardikanto, Totok dan Soebiato, 2012:43) menyatakan bahwa pemberdayaan merupakan upaya disengaja untuk memfasilitasi masyarakat lokal dalam merencanakan, memutuskan, dan mengelola sumber daya lokal yang dimiliki melalui collective action dan networking, sehingga pada akhirnya mereka memiliki kemampuan dan kemandirian secara ekonomi, ekologi, dan sosial.

Pemberdayaan masyarakat merupakan salah satu strategi yang mampu meningkatkan partisipasi masyarakat dalam pengelolaan sumber daya alam, serta mengurangi persoalan dampak lingkungan maupun ekses pengelolaan sumber daya alam. Hal ini karena kelebihankelebihan pendekatan ini dibanding pendekatan konvensional yang berlaku selama ini. Beberapa kelebihan yaitu memprioritaskan pendekatan bottom up, orientasi praxis-emansipatoris, pelestarian nilai-nilai humanisme, pendekatan ilmu sosial humaniora terbaru.

Sama dengan pemberdayaan-pemberdayaan untuk bidang-bidang lain, tujuan pemberdayaan masyarakat ekologis kultural yakni perubahan sosial. Perubahan sosial yang dimaksud yaitu aktivitas mendesain model, melaksanakan konsep, dan mengevaluasi dampak/pengaruh dari pemberdayaan itu. (Susilo, 2008) menyatakan pemberdayaan sosial dan politik kaum miskin 
sebagai dasar dari model akar rumput alternatif dari politik global dan pembangunan ekonomi. Ia meninggalkan pendekatan pertumbuhan ekonomi tidak berkelanjutan yang didasarkan pada industrialisasi dan urbanisasi yang membahayakan lingkungan.

Untuk kepentingan mencapai model masyarakat seperti ini, para ahli menentukkan indikator-indikator perubahan pada semua program pemberdayaan. Mendasarkan pada pandangan (Susilo, 2008), perubahan sosial dapat dimulai dari rumah tangga dengan menunjuk pada tiga capaian sebagai berikut.

Tabel 1. Target Perubahan Sosial dalam Pemberdayaan

\begin{tabular}{|c|c|c|}
\hline No. & $\begin{array}{c}\text { Target } \\
\text { Perubahan }\end{array}$ & Penjelasan \\
\hline 1. & $\begin{array}{l}\text { Kekuasaan } \\
\text { sosial }\end{array}$ & $\begin{array}{l}\text { Akses pada dasar- } \\
\text { dasar tertentu dari } \\
\text { produksi rumah } \\
\text { tangga, seperti: } \\
\text { inform asi, pengeta- } \\
\text { huan, ketrampilan, } \\
\text { partisipasi dalam } \\
\text { orgarisasi sosial } \\
\text { dan sumber daya } \\
\text { ?nansial. }\end{array}$ \\
\hline 2. & $\begin{array}{l}\text { Kekrasaan } \\
\text { politik }\end{array}$ & $\begin{array}{l}\text { Akses pada peng- } \\
\text { ambilan keputusan } \\
\text { yang berakibat } \\
\text { pada masa depan } \\
\text { individu sendiri. }\end{array}$ \\
\hline 3. & $\begin{array}{l}\text { Pemberdayaan } \\
\text { psikologis }\end{array}$ & $\begin{array}{l}\text { Keberhasilan diri } \\
\text { secera individual, } \\
\text { kepercayaan diri, } \\
\text { tindakan berhasil } \\
\text { dalam wilayah } \\
\text { sosial dan politik }\end{array}$ \\
\hline
\end{tabular}

Sumber: Perkins, Douglas D
Dari terma-terma pemberdayaan di atas dapat disimpulkan bahwa keberhasilan pemberdayaan diukur dari proses dan hasil. Salah satu indikator proses yaitu partisipasi dalam komunitas. Pada tingkatan organisasional, proses pemberdayaan juga meliputi pembuatan keputusan kolektif dan kepemimpinan yang dibagi-bagi, sedangkan pada tingkatan komunitas termasuk tindakan kolektif untuk mendapat akses dari pemerintah, perusahaan maupun sumber daya komunitas lain.

Sekalipun terkesan utopi, kerja-kerja pemberdayaan akan menciptakan masyarakat dinamis dan berkelanjutan melalui berbagai cara atau strategi harus tetap harus dilakukan. Hur (2006:534) menjelaskan komponen-komponen penting pada pemberdayaan, sebagai berikut.

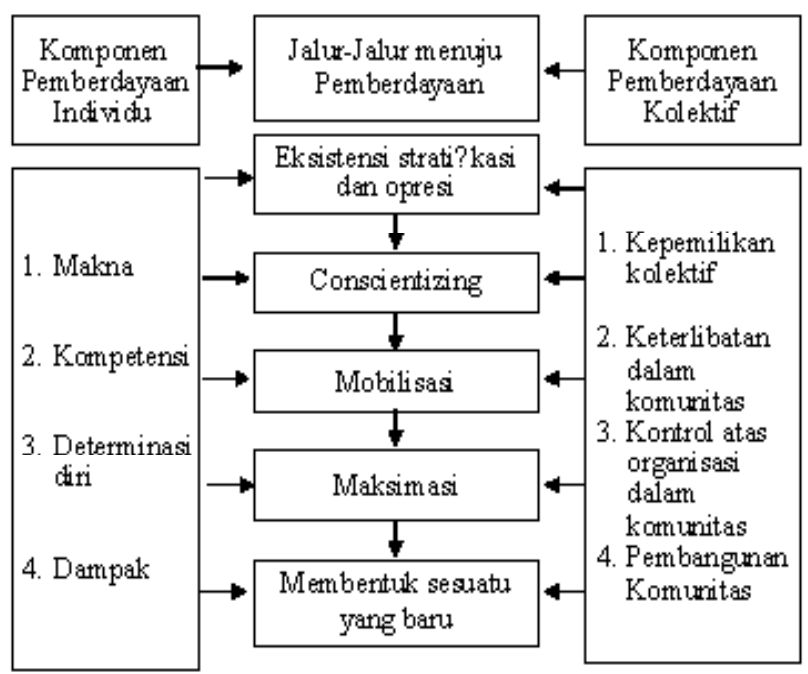

Gambar 1. Jalur Menuju dan KomponenKomponen Pemberdayaan

Seperti dijelaskan Susilo (2008) ada beragam watak manusia ketika berinteraksi dengan lingkungan, seperti: manusia sebagai penakluk lingkungan, manusia sebagai pejuang lingkungan, dan manusia sebagai perintis keberlanjutan lingkungan. Manusia tipe penakluk tidak akan bersatu dengan manusia pejuang, sebab sebuah hubungan antitesis. Sementara itu, pejuang dan perintis keberlanjutan memiliki kesamaan atas komitmen dalam menjaga 
lingkungan. Faktor yang membedakan keduanya terkait "cara". Pejuang lingkungan menempuh cara-cara radikal. Bagi mereka, lingkungan bukan hanya definisi teknis, tetapi lebih dari itu peyelamatan lingkungan membutuhkan langkah-langkah ideologis, sedangkan perintis keberlanjutan akan melihat pengembalian lingkungan dengan cara pemberdayaan. Dengan kalimat lain, tidak harus dengan cara-cara radikal.

Tujuan penelitian yaitu (1) menggambarkan best practice pemberdayaan masyarakat pada penguatan isu-isu lingkungan dan budaya local, (2) untuk menggambarkan kondisi-kondisi penentu kemunculan pemberdayaan organisasi masyarakat dalam penyelamatan lingkungan dan budaya yang berbasis pada penguatan komunitas, dan (3) menemukan model pemberdayaan masyarakat yang mampu menyelamatkan lingkungan dan melestarikan budaya lokal.

\section{METODE}

Jenis penelitian yang digunakan untuk tulisan ini yaitu kualitatif dengan pendekatan etnografi. Seperti dinyatakan oleh Le Compte and Schensul (dalam Iwan, 2010), etnografi adalah metode penelitian di mana bermanfaat untuk menemukan pengetahuan tersembunyi dalam kultur atau komunitas. Hasil deskripsi metode etnografi adalah deskripsi, penjelasan, dan teoriteori tebal (Atkinson, dkk, 2007:3). Etnografer mendengar dan merekam suara para informan dengan tujuan untuk menghasilkan gambaran atau potret kebudayaan (Cresswell, 2014:404).

Teknik pengumpulan data yaitu wawancara, observasi, dan studi arsip (dokumen). Subjek penelitian ini yaitu aktivis PPL (Pemuda Peduli Lingkungan) dan Nawakalam Gemulo. Adapun teknik pengambilan sampel yaitu purposive sampling, di mana menentukan sampel berdasarkan informasi yang dimiliki atas gerakan. Teknik pengumpulan data yaitu wawancara terstruktur dan tidak terstruktur, observasi partisipatoris, dan studi dokumen.

\section{HASIL DAN PEMBAHASAN}

\section{Kemunculan Nawakalam Gemulo}

Pemberdayaan lingkungan berbasis budaya ini berawal dari kemunculan FMPMA (Forum Masyarakat Peduli Mata Air) sebagai organisasi konservasi mata air Gemulo yang terancam oleh pembangunan hotel. Kerentanan ini karena rencana pembangunan Hotel The Rayja berjarak di bawah 200 meter dari sumber air tersebut. Bagi tokoh-tokoh FMPMA hotel akan menyebabkan kerusakan pada mata air.

Kemudian gerakan diperkuat oleh kerja sama tokoh-tokoh tiga desa (Desa Bulukerto, Desa Sidomulyo, dan Desa Bumiaji) dan LSMLSM (Yayasan Pusaka, Konservasi Brantas, MCW (Malang Corruption Watch) dan WALHI). Penghentian pembangunan hotel merupakan inti dari tuntutan-tuntutan FMPMA, karena baik pemerintah dan pihak hotel bersikukuh dengan rencana pembangunan hotel tersebut.

Akhirnya, tokoh-tokoh FMPMA menginisiasi strategi dan maneuver, seperti lobi-lobi, negosiasi, dan demonstrasi. Sebagai konsekuensi, praktik pemberdayaan lahir. Salah satu bentuknya yaitu warga sekitar mata air Gemulo membekali diri dengan bekal-bekal advokasi. Hasil pemberdayaan yaitu aksi-aksi gerakan terencana dengan baik atau dengan kata lain gerakan ini berkelanjutan.

Pemberdayaan merupakan hasil evaluasi atas keterbatasan-keterbatasan gerakan FMPMA yaitu pada saat FMPMA mengundang keterlibatan desa-desa lain. Kendala-kendala lapangan sering dialami, seperti pihak-pihak yang dilobi takut bergabung karena FMPMA dipersepsi sebagai organisasi demonstrasi.

Kasus yang paling nyata yaitu ketika FMPMA mengumpulkan pengurus HIPPAM (Himpunan Penduduk Pemakai Air Minum) se-Kecamatan Bumiaji. Ternyata para pengurus yang datang tidak banyak. Ketika berlangsung diskusi perwakilan HIPPAM tersebut banyak yang meninggalkan acara sebelum selesai. Oleh karena itu, para penggiat gerakan mengevaluasi 
bahwa kondisi ini disebabkan oleh citra FMPMA yang identik dengan demonstrasi.

Bagi tokoh-tokoh FMPMA image ini tidak menguntungkan, perlu mengubah image tersebut. Oleh karena itu, secara spontan dibentuk organisasi "anak" FMPMA yang bernama PPL (Pemuda Peduli Lingkungan) Kota Batu. Organisasi ini dibentuk sebagai kekuatan baru FMPMA. Berbeda dengan FMPMA yang dibentuk oleh aktivis-aktivis dari tiga desa, PPL dibentuk oleh pemuda-pemuda Cangar. Awalnya anggota organisasi ini hanya 4 orang yaitu Imam Yunanto, Aris, Ari, dan Edi Jabo. Kondisi ini nantinya tidak berubah, sekalipun PPL berganti mana menjadi Nawakalam Gemulo.

PPL menginisiasi kegiatan-kegiatan budaya dan lobi kepada desa-desa sekitar. Festival Mata Air I di mana salah satu tujuan untuk kampanye dan menyatukan aktivis lingkungan. Oleh karena itu, dalam Festival Mata Air tersebut, PPL ingin menunjukkan bahwa warga masih peduli kepada sumber mata air. Aris, Direktur Nawakalam Gemulo, menyatakan.

"Festival Mata Air menunjukkan banyak konteks bahwa budaya tidak menunjukkan tenaga yang banyak. Kita tidak menyerang, tetapi bagaimana mengemas sesuatu yang indah untuk melawan pemerintah. Masyarakat melihatnya sebagai kebudayaan. Selain itu, menunjukkan kalau masyarakat masih peduli dan bahkan menunjukkan kita masih perang. Ketika diikuti oleh banyak pemuda sekitar 2000, hal ini menunjukkan kepedulian mereka. Ini juga menjadi tontonan masyarakat".

Kelahiran Nawakalam Gemulo menunjukkan semakin kuatnya komitmen anakanak muda untuk memperjuangkan konservasi sumber air. Nawakalam Gemulo lahir dari kreativitas pemuda-pemudi Dusun Cangar. Sebenarnya pemuda-pemuda dari Desa Bumiaji diajak tetapi tidak bersedia karena keputusan mereka selalu bergantung kepada tokoh-tokoh tua. Kalau orang tua mendukung mereka mengikuti, kalau orang tua pasif mereka juga pasif.

Istilah Nawakalam Gemulo sendiri berasal dari tiga kata, yaitu nawak, alam dan gemulo. Nawak artinya kawan, sesuai dengan bahasa walikan (pembacaan terbalik) yang biasa digunakan warga Malang Raya, "nawak" berarti kawan atau teman. Sementara itu, alam sama dengan bahasa Indonesia yaitu alam, sedangkan, gemulo yaitu nama sumber air di Desa Buluekrto yang diperjuangkan. Sementara itu, pemahaman kedua yakni nawakalam sebagai nawa (janji) dan kalam (tertulis). Bisa dikatakan sebagai komitmen dalam memperjuangkan nilai-nilai.

Nawakalam Gemulo lebih progresif dibanding FMPMA dan PPL karena perencanaan kegiatan-kegiatan ke depan dilakukan secara lebih tertata. Sementara itu, terkait dengan keanggotaan ada perbedaan dan persamaan. Tokoh-tokoh Pemuda yang dulu bergabung di PPL juga berkiprah di Nawakalam Gemulo. Sementara itu, Nawakalam Gemulo terus merekrut sumber daya baru bersamaaan dengan aksi-aksi perjuangan penyelamatan mata air.

Kemudian Nawakalam Gemulo yang menginisiasi aksi dan demonstrasi-demonstrasi FMPMA. Baik pada waktu aksi-aksi lapang di kantor walikota maupun di pengadilanpengadilan. Ketika persidangan di Pengadilan Neger (PN) Kota Malang dan Pengadilan Tinggi Surabaya karena gugatan Hotel The Rayja kepada tokoh gerakan, pemuda-pemudi Nawakalam Gemulo melakukan aksi-aksi teatrikal di luar gedung pengadilan.

\section{Bentuk-Bentuk Pemberdayaan Konservasi Mata Air}

Konservasi mata air yang dimaksud yaitu aksi-aksi penolakan pembangunan Hotel The Rayja. Pembangunan hotel ini ditolak oleh masyarakat karena berjarak sangat dekat dengan Sumber Air Gemulo. Dekatnya jarak 
ini akan berdampak negatif pada sumber air. Padahal sumber air digunakan untuk memenuhi kebutuhan air, baik air pertanian maupun kebutuhan domestik.

Selain itu, Nawakalam Gemulo menginisiasi gerakan-gerakan konservasi seperti penanaman pohon, diskusi tentang penyelamatan lingkungan, dan berpartisipasi pada kegiatan penyelamatan lingkungan yang diselenggarakan organisasi lain. Untuk konservasi mata air, advokasi sebagai ketrampilan aktivis-aktivis organisasi ini, karena mereka bekerja sebagai aksi spontan pemudapemuda. Untuk kepentingan ini, pelatihanpelatihan para legal dan komunikasi menjadi salah satu kegiatan pemberdayaan. Para legal mempelajari pengetahuan perundang-undangan atau hukum untuk membekali kegiatan-kegiatan advokasi lingkungan, sedangkan komunikasi merupakan kemampuan menyampaikan materi atau kampanye lingkungan. Untuk keberlangsungan kegiatan-kegiatan tersebut, sukarelawan maupun pengurus MCW (Malang Corruption Watch), WALHI (Wahana Lingkungan Hidup), dan Omah Munir sering menjadi pemateri.

\section{Penguatan Kesadaran Budaya dan Isu Lingkungan}

Pemberdayaan Nawakalam Gemulo dilakukan dengan penggalian budaya-budaya lokal. Isu ekologis yang diangkat tidak secara langsung, tetapi dikemas dengan bahasa-bahasa budaya. Indra, pengurus Nawakalam Gemulo, menyatakan bahwa budaya yang dimaksud yaitu adat sosial yang mengatur bagaimana seharusnya hidup dan berperilaku, seperti slametan yang biasa diselenggarakan oleh masyarakat Jawa. Aris, Direktur Nawakalam Gumolo meyakini bahwa budaya merupakan alat efektif untuk strategi gerakan.

Penguatan kesadaran budaya dilakukan dengan mengemas kegiatan wayangan, slametan, dan tumpengan yang digabungkan dengan kampanye lingkungan. Festival Mata Air I,
27 Desember 2012, diisi dengan tumpengan dan bantengan se-Malang Raya. Panitia mengundang kelompok-kelompok bantengan dari Kota Malang, Kabupaten Malang, dan Kota Batu. Selain berkontribusi menghidupkan kesenian bantengan, kegiatan ini menyuarakan penyelamatan sumber mata air.

Festival Mata Air II, 2 Desember 2013, yaitu berbarengan dengan syukuran Dusun Cangar yang diselenggarakan pada Bulan Syuro. Kegiatan dikemas dengan parade tumpengan dan pementasan wayang dengan lakon Wahyu Tirtomoyo. Aktor-aktor penting dalam penguatan budaya yaitu tokoh-tokoh masyarakat, tokohtokoh agama, tokoh-tokoh budaya, dan tokoh perempuan.

Festival Mata Air III, 7 Nopember 2014, di Pendopo Dusun Cangar yaitu berbarengan dengan pementasan wayang dengan lakon Pandowo Babat Alas Amerta dan kirab tumpeng Dusun Cangar yang diselenggarakan pada Bulan Syuro. Selain itu, Nawakalam Gemulo menerbitkan buku kumpulan puisi mata air. Kegiatan ini dilakukan bersama komunitas-komunitas sastra dan budaya di Kota Malang. Pada saat launching buku kumpulan puisi sastrawan-sastrawan se-Jawa Timur hadir.

Festival Mata Air IV, 24 Oktober 2015, yang dikemas dengan Pentas Teriakan Bumi. Pada kegiatan ini anak-anak muda se-Kota Batu diundang untuk menampilkan musik-musik indie dan pesan-pesan lingkungan.

\section{Pemberdayaan Potensi-potensi Pemuda}

Kelahiran Nawakalam Gemulo bertujuan mengembalikan kondisi "guyub" Dusun Cangar. Langkah-langkah yang dilakukan yaitu membangun kesadaran di level pemuda. Seperti mengembalikan ikatan-ikatan ketetanggaan yang sudah mulai lemah dengan penyadaranpenyadaran kepada anak-anak muda. Seperti dinyatakan oleh Aris bahwa kemunculan Nawakalam dilatarbelakangi kesadaran akan kepedulian atas persoalan-persoalan kampung. 
Untuk kepentingan ini potensi-potensi pemuda diberdayakan seperti keterampilan sablon dan desain kartu nama. Kegiatan ini tidak berorientasi profit murni, tetapi bentuk kepedulian sosial, seperti membuatkan undangan bagi pihak yang punya hajat dan membantu fungsi silaturahmi.

Setiap Hari Jumat aktivis Nawakalam melakukan evaluasi kegiatan, sementara pada Hari Minggu mengadakan diskusi dan pelatihan. Tema-tema diskusi yaitu apapun tema yang berkaitan dengan persoalan lingkungan, sosial, pendidikan, dan mendiskusikan programprogram Nawakalam Gemulo.

Efek dari kerja Nawakalam yaitu lahirnya jejaring sosial yang bisa digambarkan sebagai berikut.

1. Keterlibatan WALHI dan komunitas-komunitas sastra mampu menarik jaringan sosial aktivis peduli lingkungan di Malang Raya untuk hadir pada acara-acara Nawakalam.

2. Keaktifan dari LSM-LSM yang mendampingi Nawakalam Gemulo. Kontribusi LSM ini selain memberikan bekal-bekal advokasi juga memberikan jejaring untuk penguatan pemberdayaan Nawakalam Gemulo.

3. Kegiatan-kegiatan yang dihadiri oleh Nawakalam seperti: pelatihan rutin yang diselenggarakan oleh WALHI, MCW, dan SPD (Sekolah Perempuan Desa).

Tiyanto, dkk memberikan makna pemberdayaan yaitu membantu komunitas dengan sumber daya, kesempatan, keahlian, dan pengetahuan agar kapasitas komunitas meningkat, sehingga dapat berpartisipasi untuk menentukan masa depan komunitas (Tiyanto, 2006:98).

\section{Perubahan-Perubahan Sosial Pasca Pemberdayaan}

\section{Meningkatnya Ketrampilan-ketrampilan Aktivis Gerakan}

Ketrampilan yang paling nyata yaitu aktivis-aktivis Nawakalam Gemulo terbiasa mengelola kegiatan-kegiatan. Digelarnya kegiatan-kegiatan Nawakalam menyebabkan kelompok-kelompok baik sebagai pegiat maupun simpatisan akan datang. Pada saat mengorganisir inilah ketrampilan keorganisasian pengurus berkembang.

Sementara itu, keterampilan-keterampilan lain yakni mengomunikasikan gagasan ke publik dan lobby ke lembaga-lembaga pemerintah. Kedua ketrampilan tersebut dimatangkan pada saat mereka bertemu dengan banyak kalangan baik perangkat kota, kecamatan, desa maupun dusun. Kemampuan komunikasi dipengaruhi kepercayaan diri sebagai efek dari meningkatnya wawasan, keterampilan, pengalaman, dan pengetahuan. Salah satunya ketika mereka melakukan advokasi dan berinteraksi dengan banyak pihak.

Kepercayaan diri juga terbentuk dikarenakan terbukanya akses sumber daya di luar dusun, seperti keterlibatan para aktivis pada kegiatan-kegiatan di level Kota Batu. Para aktivis Nawakalam diundang menghadiri kegiatankegiatan MCW dan WALHI. Juga dengan adanya organisasi ini tokoh-tokoh gerakan memonitor dan mengikuti perkembangan kegiatan di Kota Batu, sehingga tokoh-tokoh yang pernah diundang dalam kegiatan Nawakalam menjadi mitra mereka, seperti aktivis-aktivis LSM dan birokrat-birokrat Batu. Dengan demikian aktivis Nawakalam mampu memanfaatkan potensi/ sumber daya di luar dusun.

\section{Keterlibatan Aktivis pada Persoalan Dusun/ Desa}

Efek dari pemberdayaan yaitu terbuka kesadaran tokoh-tokoh Nawakalam untuk lebih memikirkan Dusun. Mereka memikirkan 
perkembangan dari generasi-generasi muda. Kemudian organisasi ini mampu merubah anakanak muda di mana sebelumnya cuek menjadi peduli. Kepedulian itu diwujudkan dengan merancang peubahan-peruahan dusun yang dikehendaki.

Hal paling kongkret yaitu usulan mereka untuk mengagas pertemuan rutin setiap Jumat legi, pertemuan ini mempertemukan perangkat dusun dengan warga. Dalam pertemuan tersebut baik moderator maupun penentuan isu didesain Nawakalam. Isu-isu yang dilontarkan merupakan kritik atas isu orang tua yang mendominasi bertahun-tahun. Pertemuan tersebut digunakan untuk membahas persoalan-persoalan dusun. Isu yang dilontarkan seperti pengelolaan sampah, air minum, dan pemanfaatan dana HIPPAM.

Kasus nyata keterlibatan Nawakalam Gemulo yaitu pemilihan kepala dusun. Aris menyatakan bahwa sampai sekarang Dusun Cangar tidak memiliki kepala dusun setelah kepala dusun diberhentikan oleh kepala desa atas desakan warga. Kekosongan ini tidak segera diisi karena proses pemilihan dinilai aktivis-aktivis Nawakalam Gemulo penuh rekayasa. Oleh karena itu, sepanjang tidak ada proses yang fair, Nawakalam Gemulo akan selalu mengkritisi.

\section{Evaluasi dan Refleksi Pemberdayaan Masyarakat}

Pemberdayaan ekologis kultural yang dilakukan Nawakalam Gemulo bermula dari kerja-kerja advokasi yang berkembang sebagai pembelajaran sosial (social learning). Pembelajaran sosial menuntut refleksi atas kerja-kerja advokasi yang telah diinisiasi sebelumnya. Hal ini menuntut aktivis-aktivis organisasi tersebut untuk memutuskan bentuk pemberdayaan yang sesuai dengan kebutuhan. Belajar dari kelemahan-kelemahan taktik advokasi yang diinisiasi sebelumnya akhirnya pemberdayaan muncul.

Pada konteks inilah lahir program-program pemberdayaan yang bertujuan menyuarakan penyelamatan mata air dengan media budaya. Oleh karena itu, penyadaran, pendidikan, partisipasi politik, dan investasi sosial merupakan bentukbentuk penguatan kapasitas aktor. Mulyanto, tokoh Nawakalam Gemulo menyatakan bahwa penyadaran dan pendidikan saling mengikat antara satu dengan lain. Pendidikan yang dimaksud yaitu pendidikan non formal yang membekali keterampilan-keterampilan.

Tujuan pemberdayaan yaitu penyelamatan mata air Gemulo. Orientasi jangka pendek dan kongkret yaitu penolakan pembangunan hotel yang diyakini akan menyebabkan resiko negatif atas sumber air. Namun, demikian pada perjalanan, isu penyelamatan tidak saja penghentian pembangunan hotel, tetapi berkembang kepada isu-isu lingkungan yang lebih luas seperti penghijauan. Pembacaan isu lingkungan juga tidak hanya dibatasi pada level dusun atau kota.

Dari berkembangnya penguatan isu lingkungan tersebut akhirnya berkembang pada pemberian ketrampilan-ketrampilan lain. Ketrampilan tersebut meliputi advokasi dan penyadaran isu-isu lingkungan. Kemudian, isu dan cakupan gerakan juga menjadi lebih luas. Jika selama ini, keterampilan mereka hanya diaktualisasikan pada lingkup desa tetapi kini sudah berkembang pada kegiatan pada level kota.

Sementara itu, partisipasi politik anak muda juga lebih meningkat ditunjukkan dari keterlibatan Nawakalam Gemulo dalam memonitor perkembangan politik dusun maupun desa, sedangkan investasi sosial mengatur kegiatan yang mencetak karakter kepemimpinan dan leader yang bersifat ideologis. Karakter ideologis seperti dinyatakan Mulyanto yaitu aktivitas Nawakalam yang berani protes, memberikan solusi, dan berani tampil di acaraacara publik.

Pada konteks di atas, pemberdayaan dalam organisasi ini yaitu memberikan kekuasaan (power) kepada kelompok-kelompok yang membutuhkan. Atkinson, dkk, (2007:56) 
pemberdayaan menekankan pada tiga hal yaitu: memperkuat link representative, memperkuat perilaku-perilaku positif, dan mendorong partisipasi politik. Pemikiran yang sama disampaikan oleh Atkinson, dkk, 2007:59) yang menyatakan bahwa ada tiga tahap dalam proses pemberdayaan, yaitu: memperkuat kapabilitas intelektual, menghadapi kesulitan dan persoalan, dan keterlibatan dalam politik.

Terkait modal manusia (human capital), gerak Nawakalam ini dimotori oleh anak-anak muda dengan antusias dan keingintahuankeingintahuan tinggi pada sesuatu yang baru. Sekali pun rata-rata berpendidikan sampai SMU, mereka terbuka dengan gagasan-gagasan baru dari pihak-pihak luar yang datang ke dusun tersebut.

Selain itu, ada kebanggaan ketika menjalankan program-program kegiatan. Penyelengggaraan rutin festival mata air ternyata melahirkan kebanggaan diri sebagai inisiator dari kegiatan-kegiatan Festival di Kota Batu. Aris menyatakan bahwa Festival Mata Air merupakan festival pertama yang kemudian dicontoh festivalfestival lain di desa-desa Kota Batu. Termasuk Festival Kampung Tani yang diselenggrakan oleh Pemerintah Kelurahan Temas. Kebanggaan anak-anak muda Nawakalam ditunjukkan bahwa festival mereka mandiri dari warga tanpa bantuan pemerintah.

Efek dari semangat pemuda ini, organisasi ini berhasil mengundang keterlibatan banyak pihak, baik lembaga-lembaga negara maupun tokoh-tokoh pejuang lingkungan dari wilayah lain. Kesempatan-kesempatan ini sering dimanfaatkan para aktivis untuk menimba keterampilan, memperoleh informasi, dan bertukar pengalamanpengalaman. Salah satu keterampilan Nawakalam ditunjukkan ketika ada benturan-benturan antar LSM, posisi organisasi mengakomodir kesemuanya. Ia tetap memosisikan sebagai pihak tengah dan terbuka dengan cara mengikuti kegiatan-kegiatan yang diselenggarakan LSM yang berkonflik tersebut. Pada kondisi ini, tokohtokoh Nawakalam memosisikan bahwa aktivis
LSM, dosen maupun politisi yang berkunjung ke Nawakalam merupakan guru-guru mereka yang seharusnya dimanfaatkan dengan baik.

Aris, Direktur Nawakalam Gemulo, menyatakan bahwa jejaring sosial menjadi pendorong besarnya Nawakalam Gemulo. Proses tersebut melahirkan wacana-wacana yang digarap anak muda, seperti "Batu pulih", di mana ini merupakan gagasan yang ingin mengembalikan kondisi alam Batu yang natural.

Kritik atas modal manusia disampaikan Yunanto, tokoh PPL. Ia mengkritik Nawakalam Gemulo yang jarang menyelenggarakan kegiatankegiatan kewirausahaan. Anggaran untuk kegiatan selama ini masih mengumpulkan uang secara mandiri dan meminta bantuan kepada para donatur. Hal ini yang membuat organisasi ini bergantung dengan dana dusun. Sebenarnya potensi ekonomi yang dapat dimanfaatkan di Dusun Cangar cukup banyak dan dengan jumlah anggota yang cukup banyak bisa diberdayakan dengan baik. Selain itu, cara kerja organisasi masih meninggalkan plus dan minus. Nawakalam Gemulo yaitu organisasi pemuda yang mengandalkan kerja-kerja informal lewat jagongan di Dusun Cangar. Dengan Jalur ini interaksi antaranggota dapat dilakukan selama 24 jam. Model ini ternyata menyisakan plus dan minus.

Sisi plus yaitu pemanfaatan waktu luang untuk kegiatan organisasi. Nawakalam dapat mewadahi jagongan anak-anak muda yang sebelumnya tidak tersalurkan. Mereka memperoleh keterampilan-keterampilan sosial, sehingga lebih terberdayakan. Kesempatan untuk belajar Nawakalam bahkan mengalahkan proses yang dilalui oleh FMPMA. Selama ini FMPMA menjadi kelompok senior dengan kurang memperhatikan nilai-nilai keswadayaan. Dapat dikatakan bahwa Nawakalam mampu melakukan kerja-kerja bonding. Artinya, Nawakalam mampu mengintegrasikan potensi-potensi anak-anak muda Cangar. Keberhasilan ditunjukkan dengan intensitas kegiatan yang cukup padat. Selain itu, penyelenggaraan kegiatan-kegiaran tertentu 
membuat organisasi ini tidak pernah mati.

Sementara itu, sisi negatif struktur sosial yaitu kondisi informal ini tidak melahirkan program-program yang terencana secara baik. Terkait dengan pengambilan keputusan, tidak semua keputusan diambil bebas oleh Nawakalam Gemulo. Selama ini hanya kegiatan pemberdayaan internal yang dapat diputuskan organisasi. Misalnya untuk menyelenggarakan pelatihan atau menerima tamu-tamu mereka tidak menggantungkan diri kepada keputusan para tokoh tua, tetapi untuk memutuskan kegiatan yang berhubungan dengan gerak FMPMA, Nawakalam masih menggantungkan diri kepada keputusan elit-elit desa. Selain itu, inisiatif Nawakalam tidak murni dari para penggiat organisasi ini. Seperti ide sablon kaos berasal dari Ridho Saiful, pendamping WALHI. Tanpa masukan itu tidak ada kegiatan penting dari Nawakalam.

Kondisi struktural ini disebabkan sebagai konsekuensi sistem sosial yang mendudukan posisi elit di atas kelompok-kelompok lain. Struktur sosial lama masih dipertahankan bahwa elit harus memerintah. Sebenarnya upaya ini dapat dicegah oleh keberadaan dari LSM pendamping, tetapi dalam koalisi LSM terjadi perpecahan. Sementara MCW mengajarkan tentang anti dominasi, WALHI malahan melestarikan dominasi tersebut. Akhirnya, pertanyaan berikutnya yaitu apakah pemberdayaan lingkungan ini benar-benar pemberdayaan kultural? Kalau iya, budaya seperti apa yang dimaksud? Apakah karena cukup menggelar bantengan, wayangan, dan tumpengan dapat dikatakan sebagai budaya?

Zaenal, budayawan Kota Batu yang juga aktivis FMPMA mengkritik aktivitas Nawakalam yang belum sepenuhnya mendasarkan kepada budaya. Budaya yang selalu dikampanyekan masih belum jelas. Kebudayaan bukanlah sesuatu yang mengikat pada diri setiap aktor, terbukti pada saat komunitas-komunitas lain menggelar kegiatan budaya, mereka jarang berpatisipasi. Menurutnya, Nawakalam Gemulo hanya menjadikan budaya sebagai alat untuk membangun solidaritas atau sebagai sarana untuk menggalang massa.
Sekali pun kegiatan kebudayaan di Sumber Gemulo sering diselenggarakan, aktivis-aktivis Nawakalam jarang melibatkan diri. Oleh karena itu, dapat dikatakan bahwa pemberdayaan kultural ini hanya sebagai instrumen untuk konservasi Sumber Gemulo. Artinya, kebudayaan adalah alat untuk kampanye lingkungan dan menggalang dukungan sebanyak-banyaknya. Bisa jadi kebudayaan adalah salah satu instrumen penting. ${ }^{1}$

\section{KESIMPULAN}

Kemunculan pemberdayaan ekologis kultural berawal dari stimuli pembangunan hotel yang ditentang oleh warga pengguna mata air yang terdiri dari tiga desa. Penentangan itu ditandai dengan lahirnya gerakan sosial. Sambil melakukan penentangan, gerakan ini menginisiasi program-program pemberdayaan yang digerakkan oleh anak-anak muda dari Dusun Cangar, Desa Bulukerto. Pemberdayaan berjalan efektif karena pengembangan jejaring sosial dan penggalian potensi-potensi budaya lokal. Kegiatan-kegiatan pemberdayaan kultutal ekologis rutin diselenggarakan.

Selain budaya, kegiatan yang lain yaitu optimalisasi potensi-potensi pemuda dan kepedulian atas persoalan komunitas. Pada konteks ini, pemberdayaan kultural tidak berdiri sendiri tetapi bergabung dengan kepentingan-kepentingan komunitas lain. Dengan demikian, ekologis kultural juga memiliki visi pengembangan komunitas.

Kritik atas pemberdayaan ini yaitu tidak menjadikan budaya sebagai sentral semua aktivitas. Seperti ketika komunitas-komunitas budaya diselenggarakan kegiatan kultural di sumber air, seringkali aktivis-aktivis Nawakalam Gemulo jarang terlibat. Pada kondisi ini konsep budaya yang ditawarkan masih sebatas instrumen untuk kepentingan penyelamatan lingkungan. Kondisi ini seringkali dipertanyakan oleh aktivisaktivis kebudayaan. 


\section{DAFTAR PUSTAKA}

Atkinson, P. \& M. H. (2007). Ethnography, Principles in Practice. New York: Routledge.

Cresswell. (2014). Penelitian Kualitatif dan Desain Riset. Yogyakarta: Pustaka Pelajar. Dharmawan, A. A. (2002). Pendekatanpendekatan Pembangunan Pedesaan dan Pertanian: Klasik \& Kontemporer, Apresiasi Perencanaan Pembangunan Daerah bagi Tenaga Pemasar Teknologi Mendukung Prima Tani,. In Sosiologi Pembangunan ( $p p$. 123-131). Malang.

Hur, M. H. (2006). Empowerment in Terms of The Exploring Typolooretical Perspective: Exploring Typology of the Process and Components across Discipline. Journal of Community Psychology, 34(5), 523-540.

Iwan, J. A. (2010). Pembangunan Berkelanjutan: Peran dan Kontribusi Emil Salim. Jakarta: $K P G$.

Mardikanto, Totok dan Soebiato, P. (2012). Pemberdayaan Masyarakat dalam Perspektif Kebijakan Publik. Bandung: Alfabeta.

Susilo, R. K. D. (2008). Sosiologi Lingkungan. Jakarta: PT. Raja Grafindo Persada.

Tiyanto, D. (2006). Mengubah dari yang Kecil. Surakarta: Circum dan Lindu Pustaka.

\section{(Footnotes)}

${ }^{1}$ Wawancara Zaenal, 26 Juli 2016 